\title{
Success of the Far Right in the 2020 Slovak Parliamentary Election within the European Context
}

\author{
Marián Bušša* \\ Alexander Dubček University of Trenčín, 91150, Trenčín, Slovakia \\ marianbussa@gmail.com
}

\begin{abstract}
:
Purpose and Originality: The paper analyzes the results of the 2020 parliamentary election in Slovakia using the theoretical framework of Norris and Inglehart (2019). The general trend of increasing support for the strongly authoritarian populist parties in the EU and in Visegrad 4 countries in particular suggest that the far right parties should be successful. Is this the case or are the wining parties defined in some other way?

Method: The position of each party on the libertarian - authoritarian axis is evaluated on the basis of secondary analysis of CHES 2014, CHES 2017 and 2019 EES studies. Ideological blocks of parties are subsequently compared in terms of their electoral success.

Results: Libertarian parties suffered a crushing defeat and did not manage to challenge the ideological dominance of authoritarianism in Slovakia, established after the 2016 election. But this did not automatically translate into victory of the far right. Slovakia did not join its neighbors to the south and north in the Visegrad 4. Instead, parties, which were defined mainly by their strong populist appeal were the real winners.

Society: The paper is trying to add to the research on the far right and of the authoritarian populism by noticing similarities between Slovak political trends and development in the advanced World.

Limitations / further research: The article is using limited data resources, which in turn limited how much insight into political development it was able offer. It was for example not able to sufficiently explain why the voters chose socially conservative populist parties and why did the more liberal parties fail. It also had quite narrow focus on specific policy issue areas, and did not focus others such as foreign policy, which could be a subject of future research.
\end{abstract}

Keywords: libertarianism, authoritarianism, populism, far right, ideology, election, party, Slovakia.

\section{Introduction}

Slovak far right invigorated in the 2016 parliamentary election. Not only did its traditional representative, the Slovak National Party (SNS) return into the parliament, but new and more extreme parties appeared there for the first time as well (Štatistický úrad SR, 2016, p. 1). Especially concerning was the success of the extreme right Kotleba - People's Party Our Slovakia (KLSNS), which created a third political camp in Slovak politics, distinct from both broadly understood center-right opposition camp and the camp led by the Direction - Social Democracy. It was therefore one of the main questions of the February 2020 election, if this third political camp is going to gain even more support. Polls suggested this was going to be the case (Praus Krabatová, 2019, p. 1) during the 2016-2016 period. What more, the polls were known to understate electoral support for the KL'SNS. In 2016 election, the KL'SNS was

* Korespondenčni avtor / Correspondence author 
virtually invisible in the polls even right before the election. So there was little reliable information on what the success of the KLSNS was going to be in 2020. There was also a question of what ideological position are the other parties - often rather ideologically fluid and versatile - going to take. The electoral result was going to decide if Slovakia would add to the general trend of increasing success of the far right in Europe as is among others documented by Norris and Inglehart (2019). If so, Slovakia would have joined the neighboring countries of Hungary and Poland, if not, it would have been a hint that the rise of far right, particularly the populist far right, was losing momentum. We argue that the far right lost some of its appeal in the 2020 election and its results showed stagnation of voter support, while conservative populist parties with more centrist ideological position became the clear winners. Convincing populist appeal, rather than eccentric ideological position, were the main key to electoral success.

\section{Theoretical framework}

In the paper we use the latest work of Pippa Norris and Ronald Inglehart as a general theoretical framework within which to analyze the case of 2020 election. In Cultural Backlash: Trump, Brexit, and Authoritarian Populism (2019, p. 341-342) these authors argue the silent revolution in values provoked a backlash against itself, which brought a steep rise of authoritarian-populist forces in the West. This combined focus on populist style of politics and the authoritarian content of policies seemed especially convenient to use in Slovak case after the 2016 election. Significant part of relevant parties had both features. The main ideological conflict seemed to be not between authoritarian and libertarian parties, but between strongly authoritarian and moderately authoritarian parties. Majority of Slovak parties were also populist.

Our questions about the 2020 election concerned two possible ideological shifts. The first was whether the main ideological conflict would shift closer towards the center of authoritarian libertarian axis in reaction to newly established and relatively popular libertarian parties. And the second whether the strongly authoritarian parties would become more successful than the moderately authoritarian ones, which would be consistent with the regional trend, already identified by Norris and Inglehart (2019, p. 9) in Poland and Hungary.

We make use of their definition of authoritarianism in this paper. It "is defined as a cluster of values prioritizing collective security for the group at the expense of liberal autonomy for the individual" (Norris, Inglehart 2019, p. 6). They state that its three value components are security, conformity to traditions and obedience to the leader. This understanding of authoritarianism is closely related to refusal of Inglehart's postmaterial values. This is important for being able to place Slovak parties on authoritarianism - libertarianism axis.

The paper also utilizes theoretical concepts of populism in its combinations with various ideological positions as defined by Peter Učen (2007, p. 50), especially the concepts of centrist populism and far right populism. This helped us to distinguish better between the ideological groups of political parties in Slovakia. 


\section{Method}

The paper is mainly relying on secondary analysis of data from the Chapel Hill Expert Surveys (CHES) of ideological positions of political parties in Western democracies. When necessary, the paper also tries to fill the missing data for parties, which were not yet included in this survey. We either tried to find matching data in different research or make an evaluation according to the electoral program of the given party.

The available data enabled us to create an updated evaluation of each party on the authoritarian - libertarian axis and the populist - pluralist axis, for the 2020 election. Of the two, the position on the first axis is more relevant. It has changed over time and can offer a good insight into the election results. Data on other ideological positions, such as the socioeconomic issues, were also available but position of parties on it was relatively stable and it offered little explanation of the election results.

The most recent data on ideological positions of the parties in Slovakia that we are going to use were measured 9 months before the 2020 election. The 2019 European Election Study is a post-election study in EU countries made in late May 2019. It uses some comparable data to those form CHES surveys but the data are concerning ideological positions of voters, not the parties. Therefore it is necessary to translate the data so that it would report on political parties themselves. We managed to do this by connecting the 1000 Slovak respondents to the parties they stated to feel close to. These data are of course less reliable than the ones from the CHES surveys, but have the advantage to be much more recent.

Based on these data we construct the positions of parties and ideological blocs of parties on libertarian - authoritarian axis and then evaluate their respective success in the 2020 election.

\section{Results}

\subsection{Populism among Slovak parties}

The Chapel Hill Expert Surveys from 2014 and 2017 offer us some data on the perceived populist features of relevant political parties in 2014 and then again in 2017 as shown in Table 1 and Table 2. We add the classification of parties by Norris and Inglehart based on the CHES 2014. This should give us some indication of populism in Slovak political parties, although we will explain in the discussion that the data is not so straightforward. 
Table 1. Evaluation of political parties in terms of various elements of populism $(0=$ Not important at all; $10=$ Extremely important) in 2014

\begin{tabular}{|c|c|c|c|c|c|c|}
\hline & $\mathrm{SaS}$ & SDKÚ-DS & Bridge & Direction-SD & NOVA & \#Network \\
\hline $\begin{array}{l}\text { 01) Salience of anti- } \\
\text { establishment and } \\
\text { anti-elite rhetoric }\end{array}$ & 5,6 & 3,4 & 3,5 & 3,7 & 5,5 & 5,8 \\
\hline $\begin{array}{l}\text { 02) Salience of } \\
\text { reducing political } \\
\text { corruption }\end{array}$ & 7,4 & 6,3 & 4,6 & 3,8 & 8,0 & 7,8 \\
\hline $\begin{array}{l}\text { 03) Evaluated as } \\
\text { populist / pluralist }\end{array}$ & pop & pop & pop & plur & pop & pop \\
\hline
\end{tabular}

\begin{tabular}{|c|c|c|c|c|c|}
\hline & SMK & OLaNO & $\mathrm{KDH}$ & SNS & Mean of parties \\
\hline $\begin{array}{l}\text { 01) Salience of anti- } \\
\text { establishment and anti- } \\
\text { elite rhetoric }\end{array}$ & 4,0 & 8,5 & 3,8 & 7,0 & 5,1 \\
\hline $\begin{array}{l}\text { 02) Salience of } \\
\text { reducing political } \\
\text { corruption }\end{array}$ & 5,3 & 8,5 & 5,7 & 4,8 & 6,4 \\
\hline $\begin{array}{l}\text { 03) Evaluated as } \\
\text { populist / pluralist }\end{array}$ & pop* & pop & pop & plur* & pop \\
\hline
\end{tabular}

Note. *: pop - populist, plur - pluralist. Adapted from CHES 2014 according to Polk et al. $(2017$, p. 6) and P. Norris - R. Inglehart (2019, p. 483-484).

In Table 2, we can see slightly different evaluation of various aspects of populism in newer dataset and parties present in the next parliament, but it shows similar results.

Table 2. Evaluation of political parties in terms of various elements of populism $(0=$ Not important at all; $10=$ Extremely important) in 2017

$\begin{array}{ccc}\text { The most important decisions } & \begin{array}{c}\text { Salience of anti- } \\ \text { should be made by }(10=\text { people; } \\ 0=\text { establishment and anti- }\end{array} & \begin{array}{c}\text { Salience of reducing } \\ \text { political corruption }\end{array}\end{array}$

\begin{tabular}{llll}
\hline 01) Direction - SD & 2,5 & 4,2 & 4,0 \\
02) KDH & 3,1 & 3,7 & 5,7 \\
03) Bridge & 3,2 & 2,9 & 5,1 \\
04) SNS & 3,5 & 5,1 & 2,7 \\
05) SMK & 3,6 & 3,5 & 3,5 \\
06) SaS & 5,2 & 5,9 & 8,3 \\
07) OL'aNO & 6,9 & 7,5 & 9,2 \\
08) KL'SNS & 7,0 & 9,5 & 7,0 \\
09) We Are Family & 7,2 & 8,5 & 7,6 \\
10) Mean & 4,7 & 5,5 & 5,9 \\
\hline
\end{tabular}

Note. Adapted from CHES 2017 according to Polk et al. (2017, p. 6).

\subsection{Position of parties on libertarian - authoritarian axis in 2014}

Data on another ideological feature of parties are shown in Table 3. It shows positions of then relevant political parties in Slovakia on five different issues, all belonging to the libertarian authoritarian ideological conflict. There are both evaluations of parties on the general scale in the first column and particular aspects of this position, so we can see in which questions is their ideological position more pronounced. 
Table 3. Positions of political parties on libertarian - authoritarian axis $(0=$ totally libertarian attitude; $10=$ totally authoritarian attitude) CHES 2014

\begin{tabular}{lccccc}
\hline & $\begin{array}{c}\text { Libertarianism/ } \\
\text { postmaterialism vs. } \\
\text { traditionalism/ } \\
\text { authoritarianism }\end{array}$ & $\begin{array}{c}\text { Attitudes to } \\
\text { immigra- } \\
\text { tion policy }\end{array}$ & $\begin{array}{c}\text { Attitudes towards the } \\
\text { integration of } \\
\text { immigrants and } \\
\text { asylum seekers }\end{array}$ & $\begin{array}{c}\text { Attitude to } \\
\text { expanding the } \\
\text { rights of ethnic } \\
\text { minorities }\end{array}$ & $\begin{array}{c}\text { Social lifestyle } \\
\text { (such as sexual } \\
\text { orientation) }\end{array}$ \\
\hline 01) SaS & 2,8 & 4,5 & 4,7 & 4,5 & 2,2 \\
02) SDKÚ-DS & 5,3 & 5,2 & 5,5 & 4,2 & 5,4 \\
03) Bridge & 5,8 & 5,4 & 4,4 & 1,0 & 5,6 \\
04) Direction-SD & 6,9 & 6,5 & 6,4 & 7,3 & 6,7 \\
05) NOVA & 7,1 & 6,7 & 8,2 & 5,7 & 7,7 \\
06) \#Network & 7,2 & 6,0 & 8,2 & 6,0 & 7,7 \\
07) SMK & 7,5 & 5,0 & 4,9 & 0,6 & 6,9 \\
08) OLaNO & 8,1 & 7,4 & 8,2 & 6,5 & 7,9 \\
09) KDH & 8,9 & 7,6 & 8,3 & 6,7 & 9,4 \\
10) SNS & 9,4 & 9,3 & 9,7 & 5,0 & 9,9 \\
11) Mean & 6,9 & 6,4 & 6,9 & 5,2 & 6,9 \\
\hline
\end{tabular}

Note. *: pop - populist, plur - pluralist: based on negative ranges. Adapted from CHES 2014 according to Polk et al. (2017, p. 6).

\subsection{Position of parties on libertarian - authoritarian axis and left - right axis in 2017}

In Table 4 we can see positions of political parties in Slovakia on five different issues all belonging to the libertarian - authoritarian ideological conflict similar to Table 3 but this time in 2017, which means that also the party composition of relevant parties has changed slightly. The not all questions are identical with the 2014 measurement, but they do represent libertarian - authoritarian ideological conflict as well.

Table 4. Positions of political parties on libertarian - authoritarian axis $(0=$ totally libertarian attitude; $10=$ totally authoritarian attitude)

\begin{tabular}{|c|c|c|c|c|c|}
\hline Party & $\begin{array}{l}\text { Libertarianism/ } \\
\text { postmaterialism } \\
\text { vs. traditionalism/ } \\
\text { authoritarianism }\end{array}$ & $\begin{array}{l}\text { Attitudes } \\
\text { to } \\
\text { immigra- } \\
\text { tion policy }\end{array}$ & $\begin{array}{c}\text { Attitudes } \\
\text { towards the } \\
\text { integration of } \\
\text { immigrants } \\
\text { and asylum } \\
\text { seekers }\end{array}$ & $\begin{array}{l}\text { Attitude to } \\
\text { expanding } \\
\text { the rights } \\
\text { of ethnic } \\
\text { minorities }\end{array}$ & $\begin{array}{c}\text { Green / } \\
\text { alternative / } \\
\text { libertarian vs. } \\
\text { traditional / } \\
\text { authoritarian / } \\
\text { nationalistic }\end{array}$ \\
\hline 01) $\mathrm{SaS}$ & 4,1 & 8,9 & 8,3 & 5,4 & 4,5 \\
\hline 02) Bridge & 4,6 & 5,9 & 4,7 & 0,8 & 4,2 \\
\hline 03) Direction-SD & 7,3 & 8,4 & 8,9 & 6,0 & 6,9 \\
\hline 04) SMK & 7,7 & 7,7 & 5,9 & 0,2 & 6,9 \\
\hline 05) OL'aNO & 7,7 & 8,3 & 8,4 & 5,8 & 6,8 \\
\hline 06) $\mathrm{KDH}$ & 8,1 & 7,2 & 8,4 & 6,2 & 7,5 \\
\hline 07) We Are Family & 8,4 & 9,1 & 9,4 & 8,5 & 8,6 \\
\hline 08) SNS & 8,6 & 9,4 & 9,6 & 7,9 & 8,7 \\
\hline 09) KL'SNS & 9,8 & 9,8 & 9,9 & 9,8 & 9,9 \\
\hline 10) Mean & 7,3 & 8 & 7,8 & 5,5 & 6,9 \\
\hline
\end{tabular}

Note. *: Adapted from CHES 2017 according to Polk et al. (2017, p. 7).

In Table 5 the same Slovak parties as in Table 4 are evaluated according to their general leftright position and according to their position on economic issues, which is not quite the same 
thing as we can see in the data. It is especially true about the far right KLSNS, which is positioned in the ideological center when we consider just its economic policies.

Table 5. Positions of political parties on general ideological axis, on socio-economic issues and on EU integration

\begin{tabular}{lcc}
\hline Party & $\begin{array}{c}\text { Overall ideological position of the party } \\
(0=\text { e. left; } 10=\text { e. right })\end{array}$ & $\begin{array}{c}\text { Ideological position on economic } \\
\text { issues }(0=\text { e. left; } 10=\text { right })\end{array}$ \\
\hline 01) Direction-SD & 3,8 & 2,9 \\
02) Bridge & 5,8 & 5,9 \\
03) SMK & 6,9 & 5,8 \\
04) OL'aNO & 6,9 & 6,7 \\
05) KDH & 7,1 & 6 \\
06) SaS & 7,4 & 8,5 \\
07) We Are Family & 7,7 & 6,7 \\
08) SNS & 7,8 & 4,7 \\
09) KLSNS & 9,7 & 5,1 \\
\hline
\end{tabular}

Note. *: Adapted from CHES 2017 according to Polk et al. (2017, p. 7)

\subsection{Libertarian vs. authoritarian values among sympathizers of political parties in 2019}

In Table 6 we can see where sympathizers of Slovak parties placed themselves on various issues representing libertarian - authoritarian axis in May 2019. In the last column we can see a composite value for each party based on the three partial scores in the first three columns. The lower the number the more libertarian are the sympathizers of given party.

Table 6. Attitudes towards libertarian / postmaterial vs. traditional / authoritarian value dimensions among voters expressing closeness to a particular party $(0=$ libertarian; $10=$ traditional $)$ in 2019

\begin{tabular}{lllll}
\hline & $\begin{array}{l}\text { Attitude to } \\
\text { The party voters feel } \\
\text { sloseness to }\end{array}$ & $\begin{array}{l}\text { Environmental protection } \\
\text { should take priority even } \\
\text { at the cost of economic } \\
\text { growth }\end{array}$ & $\begin{array}{l}\text { Importance of living in a } \\
\text { country that is governed } \\
\text { democratically }\end{array}$ & $\begin{array}{l}\text { Total of the } \\
\text { three values }\end{array}$ \\
\hline 01) PS/Together & 4,5 & 2,1 & 0,7 & 7,3 \\
02) SaS & 4,9 & 3,3 & 1,8 & 9,9 \\
03) OL'aNO & 6,3 & 2,3 & 1,7 & 10,3 \\
04) Bridge & 7,2 & 2,4 & 1,7 & 11,3 \\
05) We Are Family & 6,9 & 2,8 & 1,9 & 1,5 \\
06) Direction - SD & 7,8 & 2,4 & 1,5 & 1,6 \\
07) KDH & 8,4 & 3,0 & 1,5 & 12,8 \\
08) KLSNS & 8,2 & 2,7 & 1,9 & 1,8 \\
09) SNS & 9,3 & 2,9 & 1,8 & 1,1 \\
10) Mean of all voters & 6,6 & 2,7 & 1,7 & 1,3 \\
\hline
\end{tabular}

Note. *: Adapted from Schmitt, H. et al. (2019, p. 1).

\subsection{Success of political party blocs in 2016 and 2020 elections and parliamentary strength of political parties in 2012 to 2020}

In Table 7 we can see electoral results in the 2016 and 2020 elections for ideological blocs of parties. Which shows that the main change happened to be a shift of support from the Direction-SD to conservative populist parties, while the rest of the blocs remained at very similar positions as 4 years ago. These blocs are however not recognized in Slovak politics and we created them for the purpose of this paper on the basis of presented ideological positions of parties. 
Avgust / August 2020, leto / year 5, številka / number 3, str. / pp. 185-197.

Table 7. Electoral success of the ideological blocs in 2016 and 2020 elections

\begin{tabular}{lll}
\hline Ideological bloc & 2016 election $(\%)$ & 2020 election $(\%)$ \\
\hline 01) Direction-SD & 28,3 & 18,3 \\
02) Far right & 16,8 & 14,1 \\
03) Conservative populists & 17,6 & 33,3 \\
04) Center right & 22,6 & 23,6 \\
05) Hungarians & 10,5 & 6 \\
\hline Note. Adapted from Štatistický úrad SR (2016, p. 1) (2020, p. 1).
\end{tabular}

Finally in Table 8 we can see the parliamentary strength of political parties right after the last three elections, as well as the calculated strength based on result of November 2019 opinion poll. We can see that changes are much more significant compared to Table 7. Many parties were missing in the Parliament in at least some parliamentary terms. The current Parliament is no different and many parties which would have made it to the Parliament according to the November 2019 poll ended up without deputies.

Table 8. Numbers of deputies elected for parties in the 2012, 2016 and 2020 parliamentary election and according to the AKO Election Survey of November 2019

\begin{tabular}{lcccc}
\hline Party & Deputies 2012 & Deputies 2016 & Deputies 2020 & Deputies November 2019 poll \\
\hline Direction - SD & 83 & 49 & 38 & 32 \\
KDH & 16 & 0 & 0 & 11 \\
OLaNO & 16 & 19 & 53 & 13 \\
Bridge & 13 & 11 & 0 & 0 \\
SDKÚ-DS & 11 & 0 & 0 & 0 \\
SaS & 11 & 21 & 13 & 11 \\
SNS & 0 & 15 & 0 & 11 \\
SMK & 0 & 0 & 0 & 0 \\
KL'SNS & 0 & 14 & 17 & 18 \\
We Are Family & 0 & 11 & 17 & 12 \\
\#Network & 0 & 10 & 0 & 21 \\
PS/Together & 0 & 0 & 0 & 21 \\
For the People & 0 & 0 & 12 & \\
\hline Note *: Adapted from Štatistický úrad SR (2012, p. 1) (2016, p. 1) (2020, p. 1), Praus Krbatová (2019, p. 1).
\end{tabular}

\section{Discussion}

\subsection{Populist features among the parties in Slovakia}

In table 1 and 2 we can see, that Direction - SD, the governing party in both cases, is evaluated as the least populist. This is a bit counterintuitive since the party has long been synonymous with populism in Slovakia. Between 2014 and 2017 the tendency towards antiestablishment rhetoric and to stressing of reduction of political corruption decreased also in case of the SNS and the Bridge, after they entered the coalition government. Therefore we could estimate that for most parties the measured values indicate more their position in the government or the opposition, then their populism. The exceptions are the KDH, the SMK and the Bridge, which were not populist even while in the opposition. However, all of these non-populist parties experience fatal decline in voter support. 
In Table 1 we can see that by far the most populist party in 2014 was the Ordinary People and Independent Personalities (OLaNO). This is the most stable and most recognizable feature of the party. In Table 2 we see that in 2017, OLaNO was joined at the top by the two new parties - the conservative populist We Are Family and the far right KLSNS.

\subsection{Placement of parties on the libertarian postmaterial - authoritarian / traditional axis and ideological blocs of parties}

Norris and Inglehart (2019) pay the main attention to the position of parties on libertarian authoritarian axis. They are interested in authoritarian politics in the sense that it is a counterprinciple to libertarian and postmaterial values which increasingly dominated the West in the past several decades. We also use this point of view when evaluating Slovak parties in the Table 3 and 4 and also to some degree in Table 6. We also try to identify ideological blocs of parties in Slovakia and evaluate their electoral success, as it is summarized in Table 7.

The far right parties can be found at the authoritarian end of the libertarian - authoritarian axis. This is the axis that defines the Slovak far right, since the far right parties have moderate positions on socio-economic axis, as we can see in Table 5. The nationalist SNS was traditionally the main far right party, but since the 2016 election, it gained a competition in the form of KLSNS, an extreme right party. Another new party - We Are Family - moderated its initial ideological positions and did not become a part of the far right. Despite their ideological closeness, SNS and KLSNS do not officially cooperate. SNS is quite often a member of coalition governments, KL'SNS is refused by all other parliamentary parties. In 2020 election another party Homeland (Vlast') positioned itself ideologically between the SNS and KLSNS. But it only resulted in failure of both SNS and Homeland to get to the parliament and KL'SNS became the only representative of far right politics.

Being strongly authoritarian does not necessarily mean belonging the far right, but in Slovak case many of the most authoritarian parties are also nationalist. The main exception historically was the Christian Democratic Movement (KDH), which is strongly conservative, but not nationalist. It has a long tradition of cooperation with liberal right wing and centrist parties and together they constitute the center-right political camp.

Another small group of parties are more similar to the $\mathrm{KDH}$ than to the far right, but they are strongly populist at the same time - movements OL'aNO and We Are Family. Out of the two, OLaNO has much more centrist appeal, but as we can see in the CHES 2014 data in the Table 3 , it started at strongly conservative authoritarian positions, which it slowly moderated afterwards. It was not difficult, since it does not have many core values and is close to the centrist populism category, as defined by Peter Učeň (2009, p. 57). Something similar can be said about We Are Family - another strongly populist party, which however started off at even more radical ideological positions. What made it somewhat different from the far right parties was that these ideological positions seemed superficial and the party later abandoned them for 
more moderate ones. It makes most sense to us to treat these two parties as a group of populist parties with dominant conservative features.

The Direction - Social Democracy is the sole representative of the left in Slovak parliament and even the only relevant center left party in the party system. Despite the data shown in the Table 1 and 2, we consider it a populist party and we understand the measured values as reflecting mainly the fact that it was in power in both instances in 2014 and 2017. Učen considered it one of the centrist populist parties in Slovakia, which "mixed lukewarm leftist socio-economic policies with a harsh stance on law-and-order issues" (Učeň, 2007, p. 57). This is still valid characterization of the party today. The Direction - Social Democracy is by no means culturally liberal social democracy typical in Western Europe. Instead it quite often defends culturally conservative views and authoritarian policies. We can see that in Tables 3, 4 and 6 it usually holds the position identical to where the ideological center of Slovak politics is placed. But it does lean slightly towards the authoritarian end with progressing time.

The center right political camp is the main competition to the Direction - SD and one of these two forces usually forms the core of the coalition government. In this paper we use the current narrow definition of center right, excluding Hungarian parties and the conservative populists. This is the definition, which was colloquially used during the campaign before the 2020 election. The center right thus before the 2020 election contained the Christian democratic $\mathrm{KDH}$, the classical liberal Freedom and Solidarity $(\mathrm{SaS})$ and the modern liberal alliance Progressive Slovakia / Together - Civic Democracy (PS/Spolu) and the centrist For the People (Za Ludí). With the notable exception of $\mathrm{SaS}$, the center right is not significantly populist. And along with the Hungarian parties it represents the least authoritarian part of the Slovak political landscape. This is mainly thanks to the three new political parties in it. The first two created an alliance PS/Spolu and as we can see in Table 6, the voters close to it are the most libertarian in Slovakia. In 2019 a slightly more centrist party For the People was established. Also this party was considering joining the alliance, but ultimately it did not. In 2014 the SaS used to be the most libertarian in Slovak politics as we can see in Table 3. But it slowly abandoned some of these positions as we can see in the Table 4 and 6 . The KDH is very stable in its anti-libertarian positions, but cooperates with other parties in the center right bloc, with which it agrees on socio-economic issues as well as on the democratic character of the state as we can see in Table 5, even though the new parties are not included in it yet.

The last ideological group are the Hungarian Parties - the Bridge party (Most - Híd) and the Party of Hungarian Community (SMK). The SMK placed its candidates on a wider candidate list of MKS in the 2020 election. These parties are generally not populist nor authoritarian. In normal circumstances, they would be considered a part of the center right camp, but after 2016 election, the Bridge joined a coalition government with the Direction - SD. 


\subsection{Electoral success of the ideological blocs}

As Norris and Inglehart (2019, p. 10-11) point out, we live in the time of unexpected and significant success of strongly authoritarian parties and individual politicians using populist rhetoric. It is a challenge to find an election in Europe these days, in which victory of such party, or such candidate would not be a looming possibility. In neighboring Hungary and Poland such parties are in power. Up until 2019 such party was in the government even in Austria. And in Czechia the directly elected president represents this kind of politics. In Hungary not only the Fidesz party is in power, but its main opposition is extreme right Jobbik party.

In Slovakia this general trend had two manifestations. In the first, the already relatively populist established parties began to adopt more authoritarian ideological positions as we can see at the gradual change of the SaS and the Direction - SD in Tables 3, 4 and 6. In the second the new parties were often strongly authoritarian - the KL'SNS or the We Are Family. Even the SNS returned to the Parliament in 2016.

In the 2020 election, the far right parties represented the most authoritarian political bloc in the Slovak politics. So their success would confirm the general trend of strengthening of authoritarian populism in Europe. It is composed of three relevant parties - The strongest and the most ideologically extreme KLSNS, the nationalist radical right SNS and the Homeland established just before the election and ideologically placed between the first two. Especially the KLSNS was popular since all other parties were more moderate in their demands and the political competition was increasingly centrifugal. It also attracted many protest votes because it was shunned by other parties. The SNS had to be much more restricted, because it was in ideologically wide coalition government. Its many scandals also decreased the support for the party. Both of these parties suffered by arrival of the third rival - the Homeland party. It was criticizing the mistakes of SNS and at the same time it was not as shunned as the KLSNS. The failure of Homeland and KLSNS to find a way to cooperate and scandals of the SNS, caused that many of the votes for the far right were lost. Homeland and SNS failed to get to the parliament. KL'SNS also did not gain as many votes as the polls were suggesting. It did gain more votes than in 2016 elections but because of the higher general turnout it meant slightly smaller percentage share of votes. The far right stagnated at $14,1 \%$ of votes, which is still a considerably high number.

Another question was if the new center right parties, especially the libertarian PS/Spolu could possibly tip the ideological balance back - away from authoritarianism, where it shifted in 2016 election. PS/Spolu won the 2019 European Parliament election and its candidate won the 2019 presidential election. It had the ambition to become the strongest part of the future center right coalition. In the end it did not happen. The PS/Spolu has lost its momentum, its efforts to recruit For the People into electoral alliance failed and surprising success of the OLaNO caused that PS/Spolu did not even pass the electoral threshold of $7 \%$. Libertarian parties suffered the second defeat in a row in 2016 and 2020. As a consequence, the center right only got $23,6 \%$, which was a lot less than expected. 
The Hungarian parties gained only $6 \%$ of all votes, because of their fragmentation and the cooperation of the Bridge with the increasingly unpopular Direction - SD.

The Direction - SD was unable to hold its position of the strongest party, but even after being in power for 12 out of the last 14 years, it managed to gain $18,3 \%$ of votes.

The undisputed winner of the election were the conservative populists. They became the parties, which capitalized on decline of the Direction - SD. Even though the main political debate took place between the center right on one side and either the Direction - SD or the far right on the other. None of the center right parties managed to attract voters during the campaign as OLaNO and to lesser extent the We Are Family did. To be sure, OLaNO did criticize the Direction - SD for its corruption scandals and mismanagement of the state very loudly, actively and convincingly. There also were not such strong animosities between the conservative populists and the far right. The center right was cooperating with the conservative populists but at the same time it was losing its voters to them. This ideological bloc seemed to offer a middle way between the far fight and the center right and became the strongest group with $33,3 \%$ of all votes.

\section{Conclusion}

The 2020 election in Slovakia proved that authoritarian attitudes and populist politics are truly on the rise, supporting the general thesis of Norris and Inglehart (2019, p. 10). Libertarian parties suffered an unexpected defeat and did not manage to challenge the ideological dominance of authoritarianism in Slovakia, established after the 2016 election. But this did not automatically translate into victory of the far right. Slovakia did not join its neighbors to the south and north in the Visegrad 4. Instead, parties, which were defined mainly by their strong populist appeal were the winners. These parties carry little stable ideological baggage, but they both have clearly recognizable conservative political instincts. On the authoritarian libertarian scale they represented a middle ground of moderate authoritarianism between strongly authoritarian far right and the slightly libertarian center right.

The far right managed to gain significant share of votes $(14,1 \%)$, most of which belonged to the extreme right KL'SNS. But it failed to increase its share of votes compared to 2016 elections. Even in comparison to the pre-election polls, the far right did not reach its full potential. It however remains a relevant political force in Slovak parliament.

\section{References}

1. Norris, P., Inglehart, R. (2019). Cultural Backlash: Trump, Brexit, and Authoritarian Populism. New York: Cambridge University Press.

2. Polk, J. et al. (2017). Explaining the salience of anti-elitism and reducing political corruption for political parties in Europe with the 2014 Chapel Hill Expert Survey data," 
Research \& Politics (January-March). Vol. 4, No. 1, pp. 1-9.

https://doi.org/10.1177/2053168016686915

3. Praus Krabatová, L. (2019) Prieskum AKO: Za l’udí tesne predbehlo PS/Spolu, je lídrom opozicie. [online]. SME. 26.11.2019. Retrieved from

https://domov.sme.sk/c/22269098/prieskum-ako-za-ludi-tesne-predbehlo-ps-spolu-jelidrom-opozicie.html.

4. Schmitt, H., Hobolt, S. B., van der Brug, W. \& Popa, S. A. (2019). European Parliament Election Study 2019, Voter Study dataset. [online]. Retrieved from http://europeanelectionstudies.net/european-election-studies/ees-2019-study/voter-study2019.

5. Štatistický úrad SR. 2012. Počty mandátov pridelené politickým stranám. [online]. Retrieved from http://volby.statistics.sk/nrsr/nrsr2012/graf/graf2.jsp@lang=sk.htm.

6. Štatistický úrad SR. 2016. Počty mandátov pridelené politickým stranám. [online]. [cit. 2019-11-04]. Retrieved from http://volby.statistics.sk/nrsr/nrsr2016/sk/data02.html .

7. Štatistický úrad SR. 2016. Počty mandátov pridelené politickým subjektom a veková štruktúra zvolených poslancov. [online]. Retrieved from https://volbysr.sk/sk/data03.html

Marián Bušša is an assistant professor at the Department of Political Science at Alexander Dubček University of Trenčín. He gained. Magister degree at the Department of Political Science, Faculty of Arts at Comenius University in Bratislava, studied political theory at Prešov University and received a political science PhD. at Alexander Dubček University of Trenčín. His main focus is political culture research.

\section{Povzetek: \\ Uspeh skrajne desnice na slovaških parlamentarnih volitvah leta $2020 \mathrm{v}$ evropskem kontekstu}

Namen in izvirnost: $V$ prispevku so analizirani rezultati parlamentarnih volitev na Slovaškem leta 2020, z uporabo teoretičnega okvira Norrisa in Ingleharta (2019). Splošni trend povečanja podpore močno avtoritarnim populističnim strankam v EU, zlasti v državah Višegrada 4, kaže na to, da bi morale biti skrajno desne stranke uspešne. Ali je to res ali so zmagovalne stranke opredeljene na kakšen drug način?

Metoda: Položaj vsake stranke na libertarno - avtoritarni osi se oceni na podlagi sekundarne analize študij ESES 2014, CHES 2017 in 2019. Ideološke bloke strank se nato primerja glede na njihov volilni uspeh.

Rezultati: Libertarne stranke so doživele močan poraz in niso uspele izpodbiti ideološke prevlade avtoritarnosti na Slovaškem, vzpostavljene po volitvah 2016. A to se ni obrnilo v zmago skrajne desnice. Slovaška se ni pridružila svojim sosedom na jugu in severu v Višegradu 4. Namesto tega so bile stranke, ki so bile opredeljene predvsem po močni populistični privlačnosti, resnične zmagovalke.

Družba: Prispevek poskuša dodati raziskavi skrajne desnice in avtoritarnega populizma, tako da opazi podobnosti med slovaškimi političnimi trendi in razvojem v naprednem svetu.

Omejitve / nadaljnje raziskave: Članek uporablja omejene vire podatkov, kar je omejilo vpogled $\mathrm{v}$ ponudbo političnega razvoja. Na primer, ne more dovolj dobro razložiti, zakaj so volivci izbrali socialno konservativne populistične stranke in zakaj so bolj liberalne stranke propadle. 
Izzivi prihodnosti / Challenges of the Future,

Avgust / August 2020, leto / year 5, številka / number 3, str. / pp. 185-197.

Osredotočili smo se na specifična področja politike, ne pa tudi na druga, kot je zunanja politika, ki bi lahko bila predmet prihodnjih raziskav.

Ključne besede: libertarianizem, avtoritarnost, populizem, skrajna desnica, ideologija, volitve, stranka, Slovaška.

Copyright (c) Marián BUŠŠA

\section{(c) (7) (2)}

Creative Commons License

This work is licensed under a Creative Commons Attribution-ShareAlike 4.0 International License. 